\title{
D. Joint Memorandum to the Treasury and Civil Service Committee*
}

Sir Kit McMahon and Sir Jeremy Morse

\section{(A) What is Your View of the Brady Plan for Mexico?}

\section{Perception of Brady Initiative}

In the aftermath of the launch of Secretary Brady's Initiative, the process of debt rescheduling has been destabilised and debt service disruption increased. Ultimately the success of the debt strategy will hinge on the ability of debtor nations to implement economic programmes which reaccess - on a total voluntary basis - international capital markets. Against this objective the ambitions of the Brady Initiative look vulnerable. In particular the Initiative has:

Heavily underplayed the need of developing countries for new lending, not only to fill financing 'gaps' but also to achieve growth and thereby attract investment. The unwillingness of banks to provide new lending reflects a radical change in attitude and calls into question the future source of funds to meet the needs of the developing nations;

Raised expectations of both performing and nonperforming debtors for debt forgiveness to an unobtainable level but has failed to provide resources on a matching scale;

Placed excessive emphasis on promoting debt forgiveness which is not an end in itself and will not, in isolation, restore sustained growth and ensure access to capital markets;

Provided the wrong incentive to countries, encouraging delinquency in debt servicing and forestalling economic adjustment plans in the expectation of winning debt reduction. The better managed countries are disadvantaged;

Created a view within the banking community that debt reduction or debt service reduction aimed at bank lending in isolation is not an equitable sharing of the burden;

Broken the earlier link between IMF finance and the maintenance of interest payments to banks (the Fund will now advance credit to a country even if it is in arrears to its bankers).

\footnotetext{
* This section has been extracted from a slightly longer joint memorandum submitted to this House of Commons Committee, dated 17th January, 1990.
}

\section{Mexico Financing Package 1989-92}

In the period which has elapsed since the launch of the Brady Initiative on March 10, 1989, the creditor community has focused on Mexico as a test case.

The resulting financing package agreed between Mexico and the Advisory Committee representing commercial banks has been resisted by the wider banking community to the extent that commitments to provide a balanced response to the country's invitation have been found lacking. The dearth of new lending from the banking community reflects two major flaws in the Brady Initiative.

These are:

- the unwillingness of commercial banks to provide new lending:

The success of a Brady-inspired package rests on an appropriate measure of debt reduction and debt service reduction, accompanying a supply of new lending. Any proposal to prioritise the dual aspects of debt reduction will result in an unbalanced menu of options and the incompatibility of new lending and debt forgiveness.

Excessive emphasis on debt reduction will mean that many banks which pursue that route will consider themselves to have exited from a country and will not expect to be called upon for additional financing of any kind in the future. Lenders may seek to withdraw any remaining voluntary trade and interbank lines.

\section{- the scale of debt reduction:}

The response to the Mexican package is estimated, at best, to save the country less than $\$ 1$ bn in external interest payments each year. This is equivalent to around 10 per cent of Mexico's total interest payments to external creditors and cannot, in isolation, be expected to have a major impact on growth prospects.

The projected saving on external debt service equates to about 5 per cent of domestic interest payments and, therefore, will only have a marginal impact on the country's ability to meet domestic obligations.

Though the Mexico proposal is the largest of its kind so far attempted, the scale of achievement is insufficient to have a material impact on the country's economic prospects. As a result the Brady Initiative barely scratches the surface of the Debt Crisis. 


\section{Contribution of Creditor Community}

Once the problems confronting a country have been diagnosed then a solution should be tailored to meet the specific situation. New lending or short-term debt service reduction would be appropriate to cover a liquidity shortfall whilst debt reduction is needed when the country's solvency is at stake.

On the occasions that it is considered necessary to provide a wide ranging menu of options then voluntary debt reduction and debt service reduction, debt buy backs, new lending by banks and measures to attract private capital must be promoted as an integral package. Focus on any one component to the exclusion of the others will undermine the whole effort.

In this regard it was encouraging to hear $\mathrm{Mr}$. Brady, in his speech to the IMF in September 1989, state:

Several countries . . . are already working toward new financing packages consistent with the strengthened strategy. As they discuss their needs and options with the international financial institutions and banks, their varied interests have become increasingly clear. While reducing debt burden has been the emphasis of many, new financing is still important for many countries. Although the elements and the mix will vary from case to case, it is important that there be a proper balance between new money, debt and debt service reduction.

Therefore, new lending must be attracted through a more flexible stance in the provision of enhancements. Resources allocated by international financial institutions should be totally fungible and used in whichever way ensures maximum benefit to a country.

To ensure that the impact of an agreed financing programme is at a level which strengthens a country's economic prospects the Brady Initiative should extend beyond bank borrowing and capture the debt owed to the official sector. Rescheduling or restructuring this exposure through the Paris Club is no longer sufficient.

The longstanding debt crisis can only be resolved through cooperative effort and an equitable sharing of the burden. The political will of industrialised countries to participate in the solution - through the commitment of a meaningful amount of resources -appears to be lacking.

\section{(B) What Role should Government and the Bank of England respectively play in relation to Debts to Commercial Banks owed by Other Countries?}

\section{(i) Government}

HM Government has adopted a low profile in the debt crisis and appeared slow to react when the Brady
Initiative was launched. Chancellor Lawson emphasised his opposition to any solution which transferred the problem from the private to the public sector and initially resisted the use of IMF/IBRD funds to support interest reduction programmes.

Eventually the Government relented but, along with certain other G7 count ries, insisted on a strict set of guidelines governing the use of resources devoted towards enhancements. The guidelines are seen by many banks to be unhelpful to the smooth implementation of debt relief programmes.

Any suggestion that under the Brady Initiative the official sector is taking over the burden from the commercial banks must be dispelled.

Indirectly and through the multilateral institutions, the Government should ensure the continuation of adequate economic programmes in debtor countries and adequate conditionality between such programmes and financing packages.

Another major role played by the Government is through the Paris Club. In this area the Government has made it clear that requests for rescheduling of principal and/or interest from Third World countries will result in exclusion of that country from additional financing. In an environment in which the commercial banks are actively involved in rescheduling and are now being confronted with involuntary debt reduction it would be helpful to have a more relaxed attitude on the part of Paris Club members towards maintaining rescheduled countries on cover.

An equitable sharing of the burden would demand that Paris Club lenders afford debt relief alongside commercial banks.

It is recognised that on occasions a third-party can usefully mediate between debtor and creditor, but it is regrettable that the political interference of the US authorities in the negotiations between the Bank Advisory Committee and Mexico reached unacceptable levels.

\section{(ii) Bank of England}

The central role of the Bank has predictably been one of prudential regulation. The principal feature of regulation is the Matrix which is accepted by many as logical and onc of the more rational approaches to the problem.

Rather like most systems of country risk assessment used by banks, the Matrix suffers to a certain extent from being backward looking. It implicitly assumes that past behaviour is a guide to future behaviour. In an environment where debtor nation attitudes towards rescheduling and interest moratoria are influenced by official interventions such as the Brady Initiative previous patterns can be misleading.

A critical role for the Bank is to ensure that UK banks are not disadvantaged in relation to international competition through the provisioning guidelines set the 'Icvel playing field' concept. Under the Mexico 
proposals the Bank of England policy is heavily weighted towards debt reduction, whilst in certain other countries debt reduction and debt service reduction are treated in a similar manner with collateralised par and discount bonds deemed to constitute non-Mexican risk.

\section{(C) What is your View of the Bank of England Matrix for provisioning against Third World Debt and whether the Inland Revenue should allow against Tax, Provisions for Such Debts in Excess of the Requirements of the Matrix?}

\section{(i) The Matrix}

The Bank of England matrix has been very useful in providing an objective method of determining the relative riskiness of different countries through the 15 factor scoring system, though the Revenue and the banks have sometimes reached different scores.

Meetings between the British Bankers' Association and the Revenue on the tax deductibility of provisions against Third World debt have brought the Revenue from a position where they wanted a discount on the percentage provisions indicated by the Matrix to one where (with one exception) they broadly accept the results of the Matrix.

The exception is Brazil, where the 1988 rescheduling caused the Matrix to indicate an improvement, though the banks (and the Bank of England) believe it is an apparent rather than real improvement.

The difference of opinion over Brazil in 1988 is the only major obstacle to agreement with the Revenue of the main Country Risk Provisions for 1987 and 1988. That said, some banks contend that provisions charged in the accounts in excess of the Matrix should be allowed for tax purposes, based on the considered opinion of the bank as to the likely amount of irrecoverable debt.

\section{(ii) The Tax Legislation}

The Taxes Act 1988 states on the tax deductibility of debts:

... no sum shall be deducted in respect of:

(i) any debts, except bad debts proved to be such, and doubtful debts to the extent that they are respectively estimated to be bad, and in the case of the bankruptcy or insolvency of a debtor the amount which may reasonably be expected to be received on any such debt shall be deemed to be the value thereof.

The above section frequently poses problems when negotiating normal commercial bad debt provisions with the Revenue, almost always with the meaning of 'doubtful debts to the extent that they are respectively estimated to be bad', even where company accounts and other financial data are available. Differences of opinion arise as to the extent of the likely loss, often on the realisable values of the assets in the event of a liquidation.

If these questions pose difficulties in normal commercial situations the difficulties of estimating losses is greatly magnified when considering sovereign risks where governments, government agencies and the availability of foreign exchange for private sector debtors to discharge their obligations are factors to be taken into account. After all, it was said at one time that countries do not go bankrupt, but events over recent years might suggest otherwise.

The challenge, then, is to determine - with or without a Matrix - the extent to which Third World debts are bad. Whilst the Matrix can assist in setting a floor on the provisioning level, it could also impose a ceiling when dealing with the Revenue; because if they recognised the Matrix they would not reckon to allow relief on provisions in excess. On the other hand, if the directors of a bank have, after due consideration, estimated the extent of the irrecoverability of their Third World debt and provided for the shortfall, this can be argued to satisfy the requirements of the tax legislation, and even if the resultant provisions exceed the Matrix levels the relief should be given. The Revenue, though, have the right to question the basis on which the estimate of loss has been made.

\section{(iii) A Revised Matrix}

The most subjective feature of the existing Matrix is the alignment of the percentage provision bands against bands of scores. The present alignment was considered appropriate in 1987 and (presumably) in 1988 , but with the increased perception of risk in 1989 , many banks have moved provisioning percentages above the old readacross levels in their half yearly results, and in some cases to even higher levels since then.

The Bank of England is expected to issue a revised Matrix in the near future. It is expected that it will broadly support levels of provisions averaging around 50 per cent, i.e. the levels reached in the UK banks' 1989 half year results. Provisions above the 50 per cent level will be unlikely to be tax deductible unless the Revenue, of their own volition or under political pressure, accept the argument put forward by several of the major international banks, that their loans to Third World countries will not be recovered to any material extent. The loss may result from debt forgiveness, debt service reduction, sale of the debt, swapping for other debt or equity, or simply never being repaid.

In all these circumstances, a case could be made that losses should be allowed for tax purposes and that the relief should be given at the time that the lending bank records the estimated amount of the loss in its accounts. 